\title{
Teaching Writing in Rural Thailand: Considering New Perspectives
}

Glenn Toh

This article reports on a practical writing workshop for Thai teachers of English in a rural Thai setting. The teachers were participants in a Certificate in TEFL course sponsored by the Canadian International Development Agency (CIDA and taught by the Southeast Asian Ministers of Education Organization, Regional Language Centre (SEAMEO RELC). The genre approach to teaching writing is proposed as a way of helping teachers look beyond structural elements like vocabulary, punctuation, and spelling. The social functions and language choices of three important genres of writing, Description, Anecdote, and News Item, are examined in the article. The principles and practices may be generalizable to similar situations, that is, places where English is taught as a foreign language.

\section{Background}

English has been taught in Thailand since the mid-1800s when King Rama IV hired American missionaries to teach the royal children. In 1870 King Rama $\mathrm{V}$ founded a school to teach English and other "modern" subjects, also to royal children. The first school for the common people was established in 1878 (Sukamolson, 1998).

Although the teaching of English in Thailand found its beginnings within the portals of high places, it has not been limited to the nobility. Masavisut, Sukwiwat, and Wongmontha (1986) tell of how in Thailand,

English has been used by people of all levels of Thai society-business people, academics, government leaders, taxi drivers, and bar girls to fulfil their own objectives whether they be to obtain technical knowledge, participate in international communication, compete in international trade, develop the tourism industry, or simply to improve the family's economic well-being. (p. 197)

Rujikietgumjorn and Pojananon (1993), however, point out that the language still carries snob value, particularly in urban areas, in that "students in urban schools ambitiously attend English classes both in and out of schools because it indicates the prestige of the family" (p. 3). Their observation confirms Janyasupab's (1984) observation that English was learned with the belief that it would give candidates a better chance of being admitted "to the most prestigious high schools and colleges" (p. 1). 
However, in rural areas, Rujikietgumjorn and Pojananon (1993) describe palpable difficulties faced by teachers of English among the rural poor. In contrast with urban areas, Rujikietgumjorn and Pojananon tell of the lack of qualified teachers, information on appropriate methods, appropriate materials, and teaching aids as major problems. Textbooks are either inappropriate for the level at which they are being used, too teacher-centered, or not sufficiently current in approach. Moreover, substantive information on the teaching of English in Thailand's rural areas is yet to be readily available in major English-language teaching (ELT) journals published in Thailand. Meaningful references to ELT in rural schools are hard to find even in Pasaa: A Journal of Language Teaching and Learning in Thailand, which claims to be the oldest professional journal in English teaching in Thailand. A survey of Pasaa from 1995 to 1998 reveals that out of a total of 43 articles, none gives any treatment to ELT in rural Thai classrooms. The English Teacher, the other ELT journal published in Thailand, is similarly silent.

\section{Problems}

Thus to understand better the problems concerning the teaching and learning of writing skills in English, a survey was done among Matayom 1 and 2 (first- and second-year high school) teachers in rural districts in Surin Province in Thailand, where I conducted a workshop on the teaching of writing as part of a Certificate in TEFL program funded by CIDA and taught by staff from SEAMEO RELC. Each province in Thailand has a central or Muang district, which is considered the urban area; areas outside the Muang district are considered rural. Surin is in Thailand's northeast, where average incomes are the lowest in the country. The teachers surveyed were chosen because of their seniority and also because they were more experienced in teaching English compared with others in their schools; each had at least five years of English teaching experience.

The survey sought to find out what teachers perceived to be the main problems faced by Thai students when given a writing task. The responses of the teachers focused mainly on the structural and mechanical problems in writing. The following is a summary of the teachers' responses (see teacher responses in the Appendix).

1. learners have problems with grammar;

2. learners have limited vocabulary;

3. learners have problems with punctuation;

4. learners have problems with spelling;

5. learners have problems phrasing or expressing what they want to say. The teachers' preoccupation with grammar, punctuation, spelling, and vocabulary suggests that language is viewed very much as structure and not as meaning or communication. Thus mastery of writing skills is equated with mastery of the intricacies of traditional grammar, knowing when and how to 
punctuate sentences, having a good knowledge of vocabulary, and being able to spell. This can be seen from statements such as "Grammar structure is not correct," "They cannot spell words correctly," "They cannot use grammar and structure of the sentences correctly," "They write a passage that is so short because they could not find the words to write."

\section{Offering Teachers New Perspectives}

The teachers' responses very much vindicate Rujikietgumjorn and Pojananon's (1993) concern about the need to offer teachers methods that are more current. The teachers at the workshop were invited to consider some fresh perspectives concerning the teaching of writing.

The main objectives of the workshop were for teachers: (a) to view and understand writing as communication rather than as structure; (b) to teach learners to write different types of texts or genres; and (c) to impress on learners that each genre served a social and communicative purpose.

With these objectives in mind, it was decided that the training workshop, which was held at the provincial education headquarters, should help teachers focus on two important concepts: (a) the social functions of three important genres of writing, and (b) the language choices of these genres.

\section{Social Function}

During the workshop the teachers were asked to consider genre theory to teach writing to their students. The teachers were introduced to the notion of genre and the social functions of different genres of writing (Gerot \& Wignell, 1995). This was done through group work, each group of three or four being given an example of descriptive writing, an anecdote, and a news item. These are the genres teachers at the lower secondary level would need to teach.

\section{Passage 1}

Genre: Decriptive Writing

Social Function: to describe a person, place, or object Bangkok

Bangkok is the capital of Thailand. It is a big city. Millions of people live in Bangkok. It is a very crowded place. There are many cars, factories, banks, and shopping centers.

Bangkok has many places of interest. They are the famous Chao Phraya River, the busy Floating Market, and beautiful historical buildings like the ancient Grand Palace. It also has many first class hotels. Tourists from all over the world visit Bangkok. They come for sightseeing and also to shop for nice clothes and souvenirs.

Bangkok is certainly one of the more interesting and exciting cities in the world. 


\section{Passage 2}

Genre: Anecdote

Social Function: To share an account of an unusual or interesting incident with others

\section{A Snake at School}

Let me tell you about the time I saw a snake at school. It was towards the end of the day when all my friends had already left. I was going to the toilet up on the second floor of the building. It had been raining all day and I could see that the rice fields around the school were flooded. As I walked up the stairs, I told myself to be careful, because the steps were slippery. All of a sudden, I saw something slither up the landing. I took a second look and there it was, a four-foot long python. It was green, and had yellow markings on it. Immediately, I ran downstairs, screaming for help. There was no one around except for Khun Somsri, the sports teacher. She went up the staircase, but found no python. It must have escaped. It was very frightening for me, and in future, I will be more careful about going anywhere alone.

\section{Passage 3}

Genre: News Item

Social Function: To inform people about events of interest which have happened recently

Illegal Software Seized by Police

"Thai police have seized computer software worth almost 2 million baht from a company accused of using pirated computer programs," a computer industry alliance said yesterday. "Police confiscated the software and 52 computers after receiving complaints that the company did not have licenses for all its software," the Enterprise Computer Alliance (ECA) said. ECA, whose members include well-known software makers, praised the Thai police for their efforts to stop piracy.

"The message from this raid is clear. Companies should use legal software," said ECA Vice-President, John Luke in a statement. "Don't jeopardize your company's operations with illegal software."

ECA reported that none of the company's officials have been arrested, but criminal investigations are continuing.

The teachers were asked to look at each piece and find answers to the following lead questions: .

Of what use is this piece of writing?

When do people write pieces such as this one?

Why do people write such pieces?

Who are the people who are most likely to write such pieces? 
What is communicated through such pieces of writing?

Through the above exercise teachers were made aware of the social function of various genres of writing.

\section{Language Choice}

Teaching writing involves making students aware of language choice. Just as texts perform specific functions, the language resources of which texts are made also perform specific functions. Both texts and words are made to work or do a job.

This stage of the workshop followed logically from the previous one, except that this time the teachers' attention was drawn to the functional nature of language in the making of meaning.

To illustrate what was meant by language choices, the passages were analyzed on overhead transparency using colored pens. It was explained that the verb choices were different in the passages. At this point simple terminology used by systemic functional linguists was introduced. Thus Passage 1, Descriptive Writing, was made up mainly of relational processes (is, are, has), which express a state or attribute of being or existing. On the other hand, Passage 2, Anecdote, was made up of verbal processes (tell, scream), which signal that something was being said, and behavioral processes ( $g O$, see, walk, leave), which signal behavior. The only times when Passage 2 used relational processes were when it switched to a description of the python"It was green, and had yellow markings," and when the writer's feelings were described-"It was very frightening for me and in future, I will be more careful about going anywhere alone."

In Passage 3, News Item, it was pointed out that verbal processes (say, praise, report) similarly occurred when something was being spoken. Material processes were also present. These captured the nature of the physical action taking place or, in the words of Gerot and Wignell (1995), how "some entity physically does something ... to some other entity" (p. 55). Thus the police seize and confiscate the software, and arrest suspects. Material processes were noticeably absent in Passage 1, Descriptive Writing.

The use of different types of processes was highlighted as being an instance of how language choices are open to each writer. Different kinds of passages would be characterized by different choices (Gerot \& Wignell, 1995). So as a student-writer worked on writing different kinds of passages, he or she would have to make word choices, as different types of words performed different functions. Descriptive passages are characterized by a predominance of relational processes, anecdotes by a predominance of verbal and behavioral processes, and news items by material and verbal processes. 


\section{Use of Systemic Functional Terminology}

There was no reservation about introducing the terminology or meta-language of systemic functional linguists to the teachers. Such terminology would for them have been the sort of "new knowledge," the "scientific" terminology expected of such workshops. These would be understood and committed to memory. I observed that the Thai teachers had a way of translating new terms into their own language, and this would help them internalize the concepts. Often one could see a Thai phrase painstakingly penciled between lines or in the margin of the modules, probably as an aid to comprehension or memory. Thus the main concern was not whether there would be resistance to such terminology, but whether they would find classroom applications.

\section{Classroom Application}

As is always important with workshops for teachers, the participants needed to walk away armed with classroom applications for what had been presented. This is where the "curriculum cycle" becomes useful (Callaghan, Knapp, \& Noble, 1993). The curriculum cycle proposes four practical steps that classroom teachers can follow when planning their writing program. They are field construction, modeling, joint construction, and independent construction.

Field construction is when both teachers and pupils gather content. For example, if the pupils are going to write a descriptive piece about their provincial capital, they will need to gather some information about the place during field construction. Exactly how much time is spent on field construction is left to the teacher's discretion. With a less familiar topic field construction will take longer.

The stage after field construction is modeling. This is where the teacher uses a model passage, highlights (or elicits from the pupils) the social function of such a passage, and points out characteristic language choices to the pupils. For example, the teacher could use Passage 1, Descriptive Writing, as a model of a description. Colored pens are often useful. In the absence of an overhead projector the teacher can use the blackboard or a large piece of newsprint with the model text written on it.

After modeling the teacher does a joint construction exercise with the class. This is where the teacher acts as scribe, and both teacher and pupils jointly compose a description, for example, of their provincial capital. This, once again, can be done on the overhead projector, blackboard, or newsprint.

Finally, the pupils can work on their individual pieces of writing. This is the independent construction stage. Pupils could, for instance, be asked to write a description of their town or village. 


\section{Conclusion}

The teachers in this workshop bear heavy responsibilities in their workplaces. They have to supervise other teachers in their school, and sometimes district. They also have the unenviable job of teaching a foreign language in a situation where teaching materials and teaching aids are far from adequate. This is compounded by the fact that their work situations are often less appreciated than those of their counterparts in urban centers. Their hard work often goes unrecognized and unsung. It is hoped that this article goes a little way to address such an imbalance. Finally, it should be noted that this inservice program, like other such programs sponsored by CIDA and taught by SEAMEO RELC, was carried out not with a view to prescribing to teachers a list of "must-do's," but in a spirit of enabling them to consider newer teaching methods as being complementary to existing ones, and with the view to making their work with their pupils more meaningful, productive, and, I hope, gratifying. It must prove eminently worthwhile for trainers and sponsors of such workshops just to see the sparkle in the eyes of those who begin to see the usefulness or potential of a new idea. Students in the classrooms can only stand to benefit.

\section{The Author}

Glenn Toh has worked on CIDA and SEAMEO language teacher-training and government language proficiency projects since 1995. He has taught in Thailand, Laos, Vietnam, Singapore, Brunei, Dar es Salaam, and Australia and maintains a keen interest in developments in ELT in Indo-China. He has written articles on language and culture, the teaching of reading and writing, ESP, and other topics for Southeast Asian and international journals.

\section{References}

Callaghan, M., Knapp, P., \& Noble, G., (1993). Genre in practice. In B. Cope \& M. Kalantzis (Eds.), The powers of literacy: A genre approach to teaching writing (pp. 179-202). London \& Washington: Falmer Press.

Gerot, L., \& Wignell, P. (1995). Making sense of functional grammar. Sydney: Antipodean Educational Enterprises.

Janyasupab, T. (1984). A proposal of a questionnaire to survey the problems of primary school teachers in the implementation of the new English language syllabus in Thailand. Unpublished Research Report. Singapore: Southeast Asian Ministers of Education Organisation, Regional Language Centre.

Masavisut, N., Sukwiwat, M., \& Wongmontha, S. (1986). The power of the English language in Thai media. World Englishes, 5(2-3), 197-207.

Rujikietngumjorn, S., \& Pojananon, O. (1993). Problems of English language teaching in the rural primary schools in the northeastern part of Thailand: A case study in Khon Kaen and Kalasin. Unpublished Research Project. Singapore: Southeast Asian Ministers of Education Organisation, Regional Language Centre.

Sukamolson, S., (1998). English language education policy in Thailand. Asian Englishes 1(1), 68-91. 


\section{Appendix}

Teacher 1: Their background knowledge is inadequate. The writing of grammar structure is not correct. The problems of spelling words and using punctuation are not correct.

Teacher 2: The problem about writing is the students do not know how to write and what they write about. Therefore, before I let the students write, I would like to talk about what do they write and how do they write. For example, I asked them to write about the animal. I wrote the name of the animal on the board, "The Elephant." First I asked them about the elephant, "What do you think about the elephant?" The students answer: big animals, have four legs, big ears, small eyes, eat leaves, eat bananas, eat bamboo, live in the forest, live in the zoo, play football, pick up things, pull a log.

Teacher 3: My students have the problems about written English because they cannot spell the words or vocabularies that they hear from the teacher or from sound of the tape and they do not know the meaning of the text. For example: "I am sick" becomes "I am six." The other students in the weak groups live too far away from the good environment, and they do not interest their life. The grammar is not so good. I use to help my students by taking their vocabularies and make them to spell the words everyday, 10 words per day. The words are about the family, their school. For example, if I want them to know about objects in the curriculum, I need to teach them about the words that they must know about the objects; I must teach them about the sentences.

Teacher 4: The students cannot write free writing. They begin to write controlled writing. The students cannot understand vocabulary, grammar pattern, content and topic.

Teacher 5: They want to know grammar, they always have mistake in grammar. They always forgot full stop, comma and question mark in the sentences they write. They cannot write the right word in the right situation.

Teacher 6: Students cannot write correctly, especially spelling the vocabularies. So they take a lot of time to write because it is difficult for them. When I correct their writing, I find that there are a lot of mistakes in their writing and they cannot find out their own mistakes.

Teacher 7: Mostly, the students want to know the grammar. I found that writing always have mistakes in grammar. They forget the punctuation marks in the sentences. They always forget to put full stops, question marks and others. Lastly, they cannot find the right words in their writing and they cannot arrange the words in the correct places.

Teacher 8: It is very often that I can see my students having some problems in writing. Mostly, I saw they wanted to know grammatical points. I found that their writing always have some mistakes in grammar. Another problem 
is punctuation. They always forgot to put full stop, question marks in the sentences they wrote.

Teacher 9: My students' needs in written English are grammar, their knowledge about tense is quite bad. They feel bored when they learn grammar. Maybe they are confused with the way we use in correcting their writing work. Some correct every mistake and some use symbols for correcting. The next area they need is vocabulary. They cannot find a right word to explain what they want to write. The last one is they do not have enough detail for writing.

Teacher 10: My students' problems of writing are they do not know how to write and they do not know what they would write. That is because our students are weak in structure of language. They cannot construct the sentences. In fact, they have the ideas in their mind. If they do not know the structures and the vocabulary, they will not be able to write out the sentences. So they need to have models of writing. Teachers need to teach them the structures, sentence by sentence on and on.

Teacher 11: The problems my students face when they write are: they cannot use connectors correctly; they cannot spell words correctly; they cannot use grammar and structure of the sentences correctly; they write a passage that is so short because the could not find the words to write; the topics were difficult for them to write; they did not go through the main idea of writing when they write a passage; sometimes, they get bored because they do not want to write.

Teacher 12: The students could not spell the words correctly. They could not write the vocabulary correctly. Some topics are difficult to write. 